\title{
Assessment of Polychlorinated Biphenyls (PCBs) in Water, Sediments and Biota from E- waste Dumpsites in Lagos and Osun States, South-West, Nigeria
}

\author{
*1IIGBO, JK; ${ }^{2}$ CHUKWU, LO; ${ }^{1}$ OYEWO, EO
}

\author{
${ }^{I *}$ Department of Biological Oceanography, Nigeria Institute for Oceanography and Marine Research, Lagos, \\ Nigeria.*Email:igbojulie@yahoo.com \\ ${ }^{2}$ Department of Marine Sciences, University of Lagos, Nigeria
}

\begin{abstract}
The levels of PCBs in sediments, water, leachate and aquatic fauna (Tilapia guineensis, Callinectes amnicola and Cardiosoma armatum) found in and around e-waste dumpsites in Lagos and Osun States, South-West, Nigeria were analyzed using Gas Chromatography Electron Capture Detector (GC ECD) Agilent 7820A. All the 28 PCBs congeners studied were detected with the $\sum$ hexa-PCBs dominating in Lagos (21\%) while the $\sum$ tetra-PCBs (24\%) enriched the samples from Osun State. The concentrations of $\sum$ - PCBs in decreasing order were Lagos: sediment $>$ fish gill $>$ fish muscles $>$ water $>$ crab $>$ leachate and Osun: fish gill $>$ fish muscle $>$ sediment $>\mathrm{crab}>$ water $>$ leachate. The concentrations of total indicator PCBs ( $\left.\sum_{7} \mathrm{PCBs}\right)$ in the sediment from Lagos $(4.19 \mu \mathrm{g} / \mathrm{kg})$ and Osun $(8.58 \mu \mathrm{g} / \mathrm{kg})$ exceeded the Canadian Sediment Quality standard threshold effect level (CSQ TEL) $(0.03 \mu \mathrm{g} / \mathrm{kg})$ and the National Oceanic Atmospheric Administration threshold effect level (NOAA TEL) for fresh and marine sediments.. The calculated toxic equivalent quotient (TEQ) for fish from Lagos and Osun (3.7 and 4.4) respectively further suggests a likely occurrence of adverse effects to humans who consume the fish. This study reveals the high health and ecological risks associated with e-waste pollution in the aquatic environment.
\end{abstract}

DOI: https://dx.doi.org/10.4314/jasem.v22i4.3

Copyright: Copyright (C) 2018 Igbo et al. This is an open access article distributed under the Creative Commons Attribution License (CCL), which permits unrestricted use, distribution, and reproduction in any medium, provided the original work is properly cited.

Dates: Received: 02 March 2017; Revised: 27 March: 2018; Accepted: 6 April 2018

Keywords: e-waste, polychlorinated Biphenyls, aquatic environment, leachate

PCBs are a class of non-polar toxic chemical compounds consisting of 209 congeners (Adeyemi et al., 2009), out of which only about 130 (di- to deca-PCBs) are found in commercial mixtures. They are water soluble organic compounds with 1 to 10 chlorine atoms attached to biphenyl, which is a molecule composed of two benzene rings with a chemical formula of $\mathrm{C}_{12} \mathrm{H}_{10-\mathrm{x}} \mathrm{Cl}_{\mathrm{x}}$, where $\mathrm{x}=$ 1-10. They are also persistent organic pollutants whose effects remain long after their usage. They are used and applied widely in dielectric fluids such as in transformers, capacitors, coolants and other agricultural purposes. They are detected in a wide range of environmental compartments including biota (fish and other benthic organisms), soil, water, air, sediment, plants and animal tissue in all regions of the earth. Their reported half-lives in soil and sediment range from months to years. Due to their very low solubility in water and low volatility, most of them are contained in sediments that serve as environmental reservoirs from which they may continue to be released over a long period of time for example, the life expectancy of electrical transformers that contain PCBs is 30 years or more. (Wang and Zhong, 2011). They were synthesized for the first time in the last century and produced at an industrial level in the 1930's (Jang and Townsend, 2011).
The core indicator PCBs are the 7 ICES (International Council for the Exploration of the Sea) monitored congeners namely CB-28, CB-52, CB-101, CB-118, CB138, CB-153 and CB-180 (Boalt et al., 2014). They are listed as mandatory contaminants to be analyzed and reported within both the OSPARCOM (Oslo/Paris Convention for Protection of the Marine Environment of the North-East Atlantic (1992) and the HELCOM (Helsinki Commission) Conventions. They are also classed as priority POPs under the Stockholm Convention and the Marine Strategy Framework Directive (MSFD).

Twenty members of the 209 PCB congeners attain coplanarity (Wong and Wong, 2007). This is due to nonortho chlorine substitution in the biphenyl ring effects that is (four non-ortho substituted PCBs: CB-77, CB-81, CB-126, CB-169, IUPAC and eight mono-ortho substituted: CB-105, CB-118, CB-156, CB-157, CB167, CB-114, CB-123, CB-189, IUPAC) (Burreau et al., 2006). These are the dioxin-like PCBs (dl-PCBs) because they have a coplanar structure very similar to that of dioxins. They are known to elicit common toxic and biological responses including body weight loss, thymicatrophy, dermal disorder, hepatic damage, 
teratogenicity, reproductive toxicity, immunotoxicity, and high induction potency of 3-methyl cholanthrene type hepatic microsomal enzymes (Wang and Zhong, 2011).

Exposure to PCBs may enhance the genotoxic activity of similar compounds to cause more severe toxic effects which are explained by the binding of planar (non-ortho) PCBs and PCDD/Fs to the aryl hydrocarbon (Ah) receptor (Boalt et al., 2014). The author further mentioned that their lipophilic characteristics are responsible for their ability to bioaccumulate particularly in tissues and organs rich in lipids which leads to their consequent possible connection with carcinogenesis in living organisms. They are rapidly accumulated by aquatic organisms and bioaccumulated through the aquatic food chain. Greater relative amounts of PCBs are usually found in the liver, adipose tissue, skin, and breast milk. It has been shown that absorption by nursing infants of tetra and higher chlorinated congeners from breast milk ranges from $90 \%$ to $100 \%$ of the dose (Wang and Zhong, 2011).

Therefore, this study investigated the levels of PCBs in the leachate, water, sediment and some aquatic fauna found in and around e-waste dumpsites as well as assessed the ecological risk posed to the organisms by PCBs contamination.

\section{MATERIALS AND METHODS}

Study Areas and Collection of Surface Water, Leachate and Animal Specimen: Sampling was performed in Lagos (Alaba International Market) and Osun (Ajegunle Market) States of South-West Nigeria (Figure 1). To measure the levels of the PCBs four samplings were performed at each of the two dumpsites (point of entry into the water body, $500 \mathrm{~m}$ away from the dumpsite, $1000 \mathrm{~m}$ away from the dumpsite and $2000 \mathrm{~m}$ upstream which was the control). Surface water samples were collected from the study stations by dipping water sampler 6-7 $\mathrm{cm}$ below the surface film. Leachates samples were also collected from 10 different points around the dumpsites with a $1 \mathrm{dm}^{3}$ water sampler, mixed together and filtered using $15 \mathrm{~cm}$ whatman filter paper (Okunola et al., 2012). Both samples were stored in 1litre water bottle each with a screw cap, transported to the laboratory in a cooler of dry ice for further analysis.

Sediment samples (0-10 cm depth) were collected from the study sites using a stainless Van-Veen grab as previously described (Okunola et al., 2012). The sediment samples (100-200 g) were wrapped in aluminium foil and placed into cleaned polythene bags (Ziploc) and transported to the laboratory where they were pooled to form a composite sample for each study site. Sediments were air dried for one month and ground to powder using a laboratory mortar and pestle, passed through a $2 \mathrm{~mm}$ sieve and stored at $-2^{\circ} \mathrm{C}$ until analysed (Okunola et al., 2012). Professional anglers used gill nets of $1-3 \mathrm{~cm}$ diameter and cylindrical crab traps (Ayoola and Kuton, 2009). The biological samples used for the test were Tillapia guinensis, Cardiosoma armatum and Callinectes amnicola. The choice of the study animals was based on their availability in the environment.

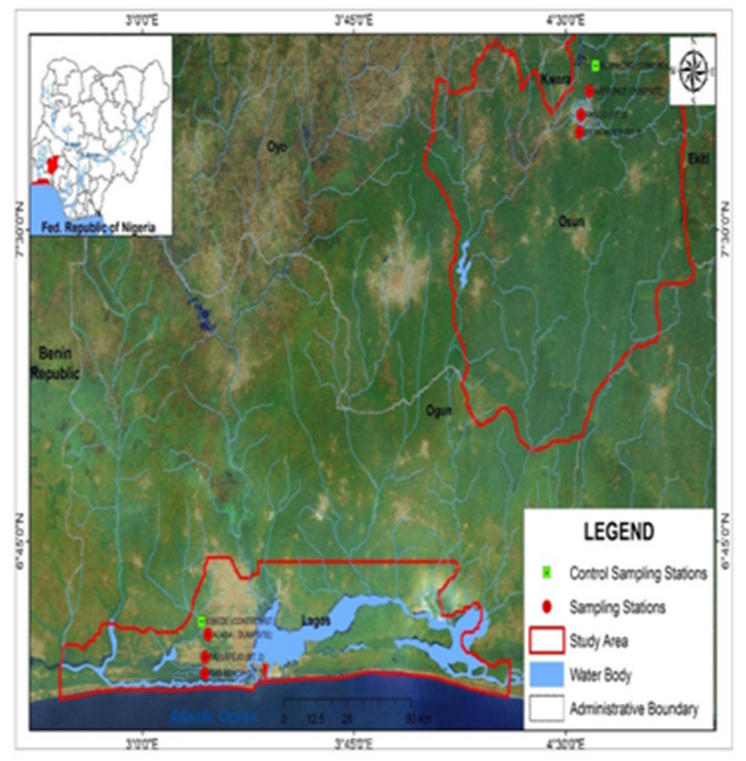

Fig 1: Map of Study Area

Determination of Polychlorinated Biphenyls (PCBs): PCBs were analyzed following a previously developed method of Chu et al., (1996). Sample aliquots of 50mL $15 \mathrm{~g}$ of sample (water, leachate/sediment and biota) were ground with $5 \mathrm{~g}$ anhydrous sodium sulfate into a dry homogenate. The biota samples were saponified with an ethanolic solution of potassium hydroxide (Baumard $e t$ al., 1998). An internal standard was added and ultrasonic extraction was used to extract PCBs from the samples with $50 \mathrm{~mL}$ hexane/acetone $(1: 1 \mathrm{v} / \mathrm{v})$. The extract was concentrated to approximately $3 \mathrm{~mL}$ by rotary evaporator. For the clean-up, the sample solution was shaken with concentrated $\mathrm{H}_{2} \mathrm{SO} 4$ in a test tube, after centrifugation, the acid layer was discarded. This treatment was repeated several times until the hexane layer was dried with anhydrous sodium sulfate, and then concentrated to approximately $1 \mathrm{~mL}$ for column chromatographic clean-up. The concentrations of 28 PCB congeners were measured by GC-ECD Agilent $7820 \mathrm{~A}$. The recovery rate of individual PCB congeners ranged from $87 \%$ to $100 \%$.

Ecological Risk Assessment (ERA): To assess toxicity posed to the benthic community, three different categories of consensus based sediment quality guidelines (SQG) namely threshold effect concentration 
(TEC), probable effect concentration (PEC) and extreme effect concentration (EEC) according to Long et al., (1995) were used.

Total Equivalent Quotient (TEQ): To express the overall toxicity of the non-ortho substituted coplanar PCBs (CB77, CB-81, CB-126, and CB-169) in the fish from each State, a TEQ was calculated according to SQuiRT by NOAA (1999)

Statistics : Concentrations of PAHs in the samples from each study site were reported as mean values. Analysis of variance was performed on all experimental data and means were compared using SPSS version 20.0 software.

\section{RESULTS AND DISCUSSION}

Distribution of individual PCB Congeners in the Studied Samples from the two Dumpsites: The total PCBs ranged from $0.22 \mu \mathrm{g} / \mathrm{L}$ in Osun leachate to $21.04 \mu \mathrm{g} / \mathrm{kg}$ in Lagos sediment (Figure 2). The concentrations of $\sum$ - PCBs were in the following decreasing order in Lagos: sediment $>$ fish gill $>$ fish muscles $>$ water $>$ crab $>$ leachate and Osun: fish gill $>$ fish muscle $>$ sediment $>$ crab $>$ water $>$ leachate. Generally relatively higher PCBs burden was recorded in Lagos $(56.21 \%)$ than in Osun (43.7\%). This was attributed to a higher density market in Lagos than in Osun. The $\sum$-hexa-PCBs dominated $(21 \%)$ in Lagos samples while Osun samples were dominated by $\sum$-tetra-PCBs accounting for about $22.84 \%$. The sum of the coplanar PCBs accounted for about $(20.2 \%)$ in Lagos and $19.4 \%$ in Osun samples, an indication of highly toxic samples (Wang and Zhong, 2011).

Distribution Patterns of Individual PCBs Congeners in Leachate from the two Dumpsites: Leachate samples from both States had the lowest recorded concentrations of PCBs congeners (Table 1). Indicator PCBs in the leachate samples were dominated by $\mathrm{CB}-52$ ranging from $0.07 \mu \mathrm{g} / \mathrm{L}$ in Lagos samples to $0.03 \mu \mathrm{g} / \mathrm{L}$ in Osun samples. Congeners CB-118, CB-153 and CB-180 were not detected in Osun while all congeners screened were present in Lagos leachate. The low levels of PCBs concentration in the leachate from both states were attributed to dilution from water. A similar observation was reported by Dannon-schaffer (2010).

Distribution Patterns of Individual PCBs Congeners in Water from the two Dumpsites: In Lagos water samples, indicator CB-28 had the highest level of $0.57 \mu \mathrm{g} / \mathrm{L}$ while the lowest recorded level occurred in CB-180 (0.11 $\mu \mathrm{g} / \mathrm{L})$ as shown in Table 1. All the coplanar PCBs screened were detected in Osun water with CB-156 having the highest occurrence $(0.79 \mu \mathrm{g} / \mathrm{L})$ while the lowest level was CB-157 (0.23 $\mu \mathrm{g} / \mathrm{L})$. When the concentrations of these contaminants in the water bodies are high, the sediments may accumulate excessive quantities that will directly or indirectly disrupt the ecosystem causing significant contamination and loss of desirable species (Burton, 2002).

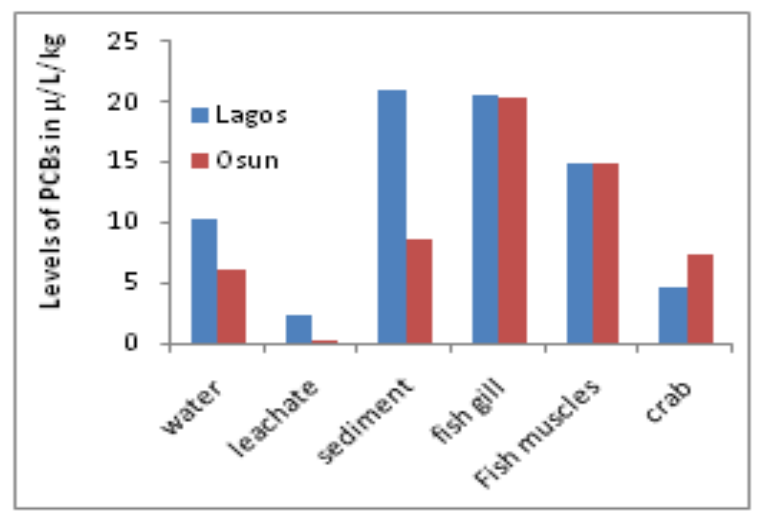

Fig 2: Total concentrations of PCBs congeners in Osun and Lagos ewaste $(\mathrm{n}=8)$

Distribution Patterns of Individual PCBs Congeners in Sediment from the two Dumpsites: In Table 1 the highest recorded level of PCBs congeners occurred in Lagos sediment $(16.02 \%)$ while the most dominant indicator PCBs in Lagos was CB-118 $(1.73 \mu \mathrm{g} / \mathrm{kg})$ and the lowest in concentration was CB-180 $(0.11 \mu \mathrm{g} / \mathrm{kg})$. In Osun CB28 was observed to have the highest level of $0.56 \mu \mathrm{g} / \mathrm{kg}$ with the lowest level of $0.15 \mu \mathrm{g} / \mathrm{kg}$ recorded for CB-180. The high level of PCBs found in the sediments have been widely reported (Wong and Wong, 2007; Wang and Zhong, 2011) and it is suggestive of the fact that persistent organic pollutants are strongly particle associated due to their hydrophobic properties and tend to be accumulated in sediments ((Apitz et al., 2006; Gomez-Gutierrez et al., 2007).

Distribution Patterns of Individual PCBs Congeners in Biota from and around the two Dumpsites: All the 7 indicator PCBs investigated were detected in Lagos and Osun crabs (Table 1). Congener CB-101 had the highest level of indicator PCBs $(0.22 \mu \mathrm{g} / \mathrm{kg})$ in Lagos crab while congener CB-28 dominated in Osun crab $(0.92 \mu \mathrm{g} / \mathrm{kg})$. Out of the 12 coplanar PCBs (non and mono-ortho) investigated, it was observed that CB- 156 had the highest concentration of $0.71 \mu \mathrm{g} / \mathrm{kg}$ in Lagos crab while Osun crab was dominated by CB-126 $(0.72 \mu \mathrm{g} / \mathrm{kg})$ in Osun crab. 
Table 1: Concentration of PCBs in water, leachate $(\mu \mathrm{g} / \mathrm{L})$, sediment, Tilapia guineensis (muscles and gill) and crab (Callinectes amnicola and Cardiosoma armatum) $\mu \mathrm{g} / \mathrm{kg}$ from Lagos and Osun States

\begin{tabular}{|c|c|c|c|c|c|c|c|c|c|c|c|c|}
\hline \multicolumn{7}{|c|}{ Lagos } & \multicolumn{6}{|c|}{ Osun } \\
\hline Congeners & water & leach & Sed & $\begin{array}{l}\text { Fish } \\
\text { gill }\end{array}$ & $\begin{array}{l}\text { Fish } \\
\text { muscles }\end{array}$ & Crab & Water & leach & sed & $\begin{array}{l}\begin{array}{l}\text { Fish } \\
\text { gill }\end{array} \\
\end{array}$ & $\begin{array}{l}\text { Fish } \\
\text { muscles }\end{array}$ & crab \\
\hline CB8 & 0.62 & 0.27 & 5.28 & 1.26 & 2.83 & 0.14 & 0.15 & ND & 0.77 & 0.72 & 0.70 & 0.81 \\
\hline$\sum$ di-PCB & 0.62 & 0.27 & 5.28 & 1.26 & 2.83 & 0.14 & 0.15 & ND & 0.77 & 0.72 & 0.70 & 0.81 \\
\hline CB18 & 1.08 & 0.07 & 1.07 & 1.27 & 1.82 & 0.20 & 0.66 & 0.02 & 0.50 & 0.99 & 3.86 & 0.56 \\
\hline CB28 & 0.57 & 0.06 & 0.78 & 0.48 & 0.40 & 0.13 & 0.23 & 0.02 & 0.56 & 0.50 & 0.17 & 0.92 \\
\hline$\sum$ tri-PCB & 1.65 & 0.13 & 1.85 & 1.75 & 2.22 & 0.33 & 0.89 & 0.04 & 1.06 & 1.49 & 4.03 & 1.48 \\
\hline CB44 & 0.44 & 0.05 & 0.59 & 0.44 & 0.78 & 0.07 & 0.23 & ND & 0.34 & 0.36 & 0.31 & 0.15 \\
\hline CB52 & 0.39 & 0.07 & 0.46 & 0.50 & 1.35 & 0.10 & 0.44 & 0.03 & 0.20 & 0.50 & 0.32 & 0.22 \\
\hline CB60 & 0.40 & 0.04 & 0.93 & 0.63 & 0.35 & 0.12 & 0.23 & 0.02 & 0.34 & 0.67 & 0.31 & 0.16 \\
\hline CB77 & 0.53 & 0.01 & 1.31 & 0.33 & 0.54 & 0.12 & 0.27 & ND & 0.45 & 0.68 & 0.33 & 0.15 \\
\hline CB101 & 0.39 & 0.05 & 0.87 & 1.05 & 0.60 & 0.22 & 0.15 & 0.02 & 0.42 & 0.93 & 0.79 & 0.17 \\
\hline CB81 & 0.47 & 0.05 & 0.48 & 0.92 & 0.57 & 0.23 & 0.05 & ND & 0.43 & 1.50 & 0.62 & 0.28 \\
\hline CB105 & 0.31 & 0.03 & 0.28 & 0.69 & 0.25 & 0.06 & 0.04 & 0.02 & 0.07 & 0.56 & 0.54 & 0.08 \\
\hline$\sum$ tetra-PCB & 2.93 & 0.30 & 4.92 & 4.56 & 4.44 & 0.92 & 1.41 & 0.09 & 2.25 & 5.20 & 3.22 & 1.21 \\
\hline CB114 & 0.37 & 0.05 & 0.57 & 1.08 & 0.39 & 0.10 & 0.34 & 0.02 & 0.58 & 0.77 & 0.98 & 0.22 \\
\hline CB118 & 0.43 & 0.06 & 1.73 & 0.19 & 1.95 & 0.14 & 1.38 & ND & 0.18 & 0.45 & 0.22 & 0.13 \\
\hline CB123 & 0.31 & 0.06 & 0.28 & 0.98 & 0.43 & 0.11 & 0.11 & ND & 0.11 & 0.82 & 0.67 & 0.11 \\
\hline CB126 & 0.25 & 0.35 & 0.25 & 0.55 & 0.17 & 0.15 & 0.06 & 0,02 & 0.22 & 0.46 & 0.27 & 0.72 \\
\hline Epenta-PCB & 1.36 & 0.52 & 2.83 & 2.80 & 2.94 & 0.50 & 1.89 & 0.04 & 1.09 & 2.50 & 2.14 & 1.18 \\
\hline CB128 & 0.11 & 0.03 & 0.19 & 0.89 & 0.09 & 0.14 & 0.05 & ND & ND & 0.81 & 0.23 & 0.18 \\
\hline CB138 & 0.23 & 0.03 & 0.11 & 1.16 & 0.15 & 0.12 & 0.11 & 0.02 & 0.22 & 0.70 & 0.30 & 0.18 \\
\hline CB153 & 0.24 & 0.06 & 0.09 & 1.61 & 0.39 & 0.18 & 0.05 & ND & 0.16 & 1.43 & 0.23 & 0.26 \\
\hline CB156 & 0.79 & 0.09 & 0.70 & 1.16 & 0.69 & 0.71 & 0.51 & ND & 0.81 & 1.12 & 0.30 & 0.37 \\
\hline CB157 & 0.23 & 0.03 & 0.12 & 1.39 & 0.28 & 0.31 & 0.14 & ND & 0.30 & 0.76 & 0.36 & 0.24 \\
\hline CB167 & 0.17 & 0.03 & 0.04 & 0.65 & 0.11 & 0.07 & 0.09 & 0.02 & 0.04 & 0.63 & 0.09 & 0.22 \\
\hline CB169 & 0.25 & 0.08 & 0.11 & 0.51 & 0.10 & 0.21 & 0.06 & ND & 0.11 & 0.58 & 0.15 & 0.20 \\
\hline$\sum$ hexa-PCB & 2.02 & 0.35 & 1.36 & 7.37 & 1.81 & 1.74 & 1.01 & 0.04 & 1.64 & 6.03 & 1.66 & 1.65 \\
\hline CB170 & 0.11 & 0.03 & 0.18 & 0.50 & 0.09 & 0.10 & 0.10 & ND & 0.17 & 0.47 & 0.17 & 0.17 \\
\hline CB180 & 0.13 & 0.03 & 0.15 & 0.90 & 0.10 & 0.11 & ND & ND & 0.15 & 0.77 & 0.31 & 0.13 \\
\hline CB185 & 0.19 & 0.05 & 0.24 & 0.44 & 0.16 & 0.51 & 0.16 & ND & 0.29 & 0.56 & 0.10 & 0.17 \\
\hline CB189 & 0.10 & 0.05 & 0.14 & 0.39 & 0.08 & 0.09 & 0.09 & ND & 0.42 & 0.52 & 0.08 & 0.14 \\
\hline Ehepta-PCB & 0.53 & 0.16 & 0.77 & 2.23 & 0.43 & 0.81 & 0.39 & ND & 1.03 & 2.34 & 0.66 & 0.61 \\
\hline CB195 & 0.10 & 0.03 & 0.36 & 0.29 & 0.04 & 0.11 & ND & ND & 0.20 & 0.28 & ND & 0.13 \\
\hline Eocta-PCB & 0.10 & 0.03 & 0.36 & 0.29 & 0.04 & 0.11 & ND & ND & 0.20 & 0.28 & ND & 0.13 \\
\hline CB206 & 0.08 & 0.04 & 0.15 & 0.11 & 0.09 & 0.06 & 0.11 & ND & 0.32 & 0.63 & ND & 0.06 \\
\hline$\sum$ nano-PCB & 0.08 & 0.04 & 0.15 & 0.11 & 0.09 & 0.06 & 0.11 & ND & 0.32 & 0.63 & ND & 0.06 \\
\hline CB209 & 1.02 & 0.50 & 3.57 & 0.29 & 0.09 & 0.03 & 0.23 & ND & 0.22 & 1.20 & 2.54 & 0.18 \\
\hline$\sum$ deca-PCB & 1.02 & 0.50 & 3.57 & 0.29 & 0.09 & 0.03 & 0.23 & ND & 0.22 & 1.20 & 2.5 & 0.18 \\
\hline$\sum$ total PCBs & 10.31 & 2.24 & 21.04 & 20.65 & 14.89 & 4.65 & 6.04 & 0.22 & 8.58 & 20.38 & 14.96 & 7.32 \\
\hline $\begin{array}{l}\sum \text { ICES } \\
\text { indicator } \\
\text { PCBs }\end{array}$ & 2.38 & 0.36 & 4.19 & 5.89 & 4.94 & 1.00 & 2.36 & 0.09 & 1.89 & 5.28 & 2.34 & 2.01 \\
\hline $\begin{array}{l}\text { *coplanar } \\
\text { PCBs }\end{array}$ & 4.21 & 0.92 & 5.90 & 7.84 & 5.56 & 2.30 & 3.14 & 0.08 & 3.72 & 8.85 & 4.61 & 2.86 \\
\hline
\end{tabular}

ND-not detected (or value 0.00), Total International Council for the exploration of the sea (ICES) indicator PCBs=sum of concentrations of PCB-28, -52, -101, -118, $-138,-153,-180{ }^{*}$ Total dioxin-like (coplanar) PCBs = Sum of concentration of PCB -77, -81, -105-114, -123-118-126-156,-157-167-169 and -189

Congener CB-118 a coplanar PCB had the highest recorded concentration of $1.95 \mu \mathrm{g} / \mathrm{kg}$ in fish muscles from Lagos while fish gill from Osun accumulated the highest recorded level of the pollutant $(21.5 \mu \mathrm{g} / \mathrm{Kg})$ than all other samples from the State.This result further confirms that these pollutants are absorbed by organisms directly from the water through their gills, hard exoskeleton, head, telson and other tissues (Onwumere, et al., 1990). The levels of the non-ortho- substituted PCBs in fish from both Lagos and Osun States respectively were higher than the NOAA (1998) fish TEF. This has a serious health implication as coplanar PCBs are known to elicit common toxic and biological responses (Wang and Zhong, 2011). Relatively higher PCBs levels occurred in the dry than in the wet seasons (Figures 3 and 4). Water and sediment from Station 2 in Lagos State were more enriched with PCBs than other stations, while in Osun State station 1 was the most polluted with the $\sum$ penta PCBs having the highest concentration in water (Figure 5). This was attributed to the nature of the water bodies in the two States. Water in Lagos is lotic while that of Osun is lentic.
Evaluation of Ecological Risk Assessment

The concentration of total indicator PCBs ( $\sum_{7} \mathrm{PCBs}$ ) in the sediment from Lagos $(4.19 \mu \mathrm{g} / \mathrm{kg})$ and Osun $(8.58$ $\mu \mathrm{g} / \mathrm{kg})$ exceeded the CSQ TEL $(0.03$ $\mu \mathrm{g} / \mathrm{kg}$ ) and the NOAA TEL levels for fresh and marine sediments. The levels of the non-ortho- substituted PCBs (CB-77, CB-81, CB-126, and CB-169) in fish from both States were found to be higher than the NOAA (1998) fish TEF. The calculated TEQ for fish from Lagos and Osun were found to be 3.7 and 4.4 respectively. 


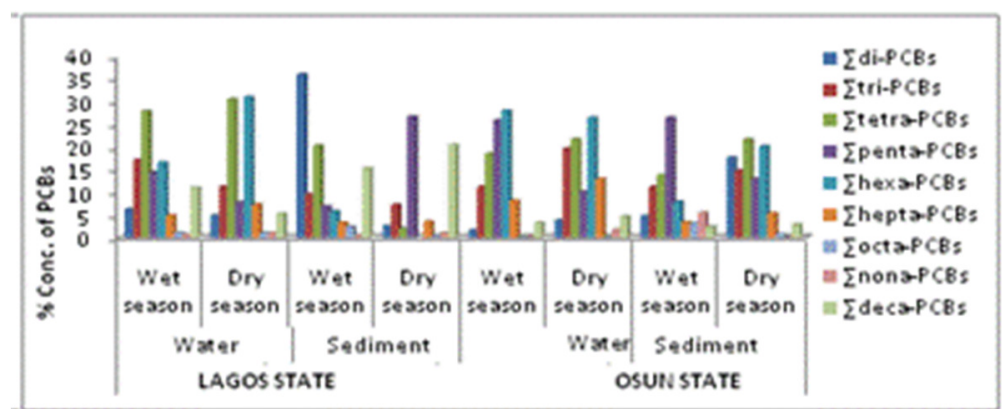

Figure 3: Percentage Seasonal Variation of PCBs found in the Water and Sediment Samples from Lagos and Osun e-waste dumpsites.

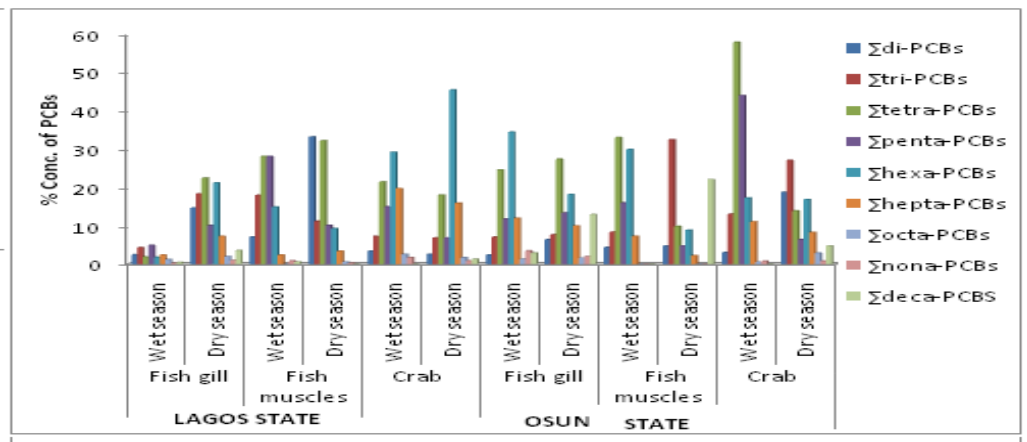

Figure 4: Percentage Seasonal Variation of PCBs in Tilapia guineensis (gill and muscles) and crab (Callinectes amnicola and Cardiosoma armatum) from Lagos and Osun States

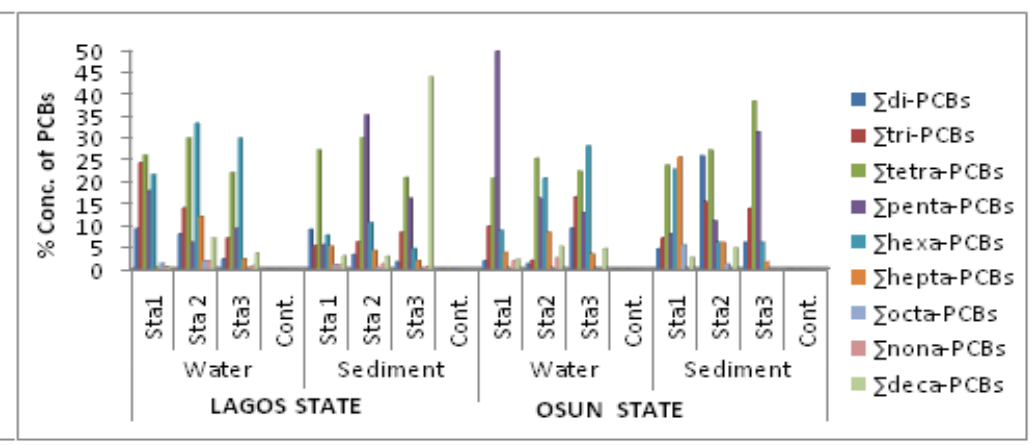

Figure 5: Percentage Spatial variations of the Percentage Concentrations of PCBs in Lagos and Osun States.

This is suggestive of a likely frequent toxic occurence to the benthic community which is of ecological risk.Also the result further show that consumption of this fish from these contaminated sites by humans is likely to cause serious adverse health effects. A study by Qing et al., (2006) reported that the United States Environmental Protection Agency (USEPA) has classified PCBs as probable human carcinogens (Group B2). The study reported that as at 1998, 37 states in the United States of America have issued 679 fish advisories for PCBs. These advisories educate the public on the high concentrations of PCBs found in local fish at levels of public health concern and recommend either limiting or avoiding consumption of certain fish from specific water bodies (USEPA, 1999).

Acute and chronic high-level exposures of laboratory animals to PCBs have resulted in liver and kidney damage, neurological effects, developmental effects, endocrine effects, hematological effects, and death. This has made PCBs to be included in the list of priority pollutants that have attracted global attention (Osibanjo, 2012).

\section{Conclusion:}

Finally, this study established the environmental risk and contamination of water, sediment and biota by PCBs in South-West Nigeria. It also revealed that the levels of nonortho and indicator PCBs in sediments and fish in both States exceeded the CSQ TEL and the NOAA TEL (1998) acceptable limit standards for fresh and marine sediments as well as the fish TEF. Consequently from the above findings, it is obvious that there is urgent need for a concerted effort to be made by the relevant authorities to address the environmental and health hazards posed by the exposure to ewaste.

\section{REFERENCES}

Adeyemi, D; Ukpo, D; Anyakora, D; Uyimadu, JP (2009). Polychlorinated biphenyls in fish samples from Lagos lagoons Nigeria. AJB8 (12): 281-2815.

Aptiz, S; Brils, J; Antonio, M; Andrea, C; Tomas, L; Katarina, D (2006). Approaches and Frameworks for managing contaminated sediments: A European Perspective. In: Assessment and Remediation of contaminated sediments: Proceedings of the NATO advanced research workshop on Assessment and Remediation of contaminated sediments 2005, Bratislava, lava, Slovak Republic. p.5-82.

Ayoola, SO; Kuton, MP (2009). Seasonal Variation in Fish Abundance and Physicochemical Parameters of Lagos Lagoon, Nigeria, Afri. J. Environ. Sci. and Technol. 3 (5):149156. 
Baumard, P; Budzinski, H; Michon, Q; Garigues, P;Burgeot, BT (1998) Origin and bioavailability of Sediment records. Estuar. Coast. Shelf Sci: 47:77-90.

Boalt, E; Miller, A; Dahlgren, H (2014). Distribution of cadmium, mercury and lead in different body parts of Baltic herring (Clupea harengus) and perch (Perca fluviatilis): Implications for environmental status assessments. Marine Poll. Bull. 78: 130-136.

Burreau, S; Zebuhr, Y; Bromar, D; Ishan, R (2006) Biomagnification of PBDES and PCBs in food webs from the Baltic sea and Northern Atlantic Ocean. Sci. Total environ. 366: $659-672$.

Burton, AG (2002). Sediment quality criteria in use around the world. Limnology 3: 65-75.

Chu, S; Yang, C; Xu, X (1996) Determination of Polychlorinated biphenyl congeners in environmental samples. J. Environ. Sci.8: 57-63

Danon-Schaffer, MN (2009) Polybrominated diphenyl ethers in landfills from electronic waste. $\mathrm{PhD}$ thesis. The University of British Columbia, Vancouver, 2010. p.362

Environmental Canada (2006). Supporting working Document for the Environmental screening Assessment of polybrominated Dipheny Ether. Environment Canada, Gatineau. P.222.

Gomez Gutierrez, A; Garnacho, E; Bayona. M; Albanges, J (2007). Screening ecological risk assessment of persistent organic pollutants in Mediterranean Sea sediments. Environ. Int.33: 867-876.

Gomez-Gutierrez, A; Gamacho, E; Bajona, JM; Albaiges, J (2007). Assessment of the Mediterranean sediments contamination by persistent organic pollutants. Environ. Poll.12:10-14

Jang, YC; Townsend, TG (2011). Leaching of lead from computer printed wire boards and cathode ray tubes by municipal solid waste landfill leachates. Environ. Sci. Technol.37:4778-84.

Long, ER; MacDonald, DD; Smoth, SL; Calder, F (1995). Incidence of adverse biological effects within ranges of chemical concentrations in marine and estuarine sediments. Environ. managet. 19:81-97.

NOAA (National Oceanic and Atmospheric Administration) (1999) Screening quick reference tables (SquiRTs) $<\mathrm{http}: / /$ response.restoration.noaa.gov/cpr/sediment/squirt/squirt. html. Last viewed 03/07/15

Okunola, AA; Bakare, AA (2011). Genotoity and mutagenicty of electronic waste leachate using animal bioassays. Toxicol. Environ. Chem. 93(5): 1073-1088.

Okunola, AA; Bakare, AA; Xijun, K; Bin L; Yuling, Z; Xia, $H$ (2012). Comparative evaluation of environmental contamination and DNA damage induced by electronic wastes in Nigeria and China. Sci. Total Environ.423: 62 72 .

Onwumere, BG; Olademeji, AA (1990). Accumulation of metals and histopathology in Orochromis niloticus exposed to treated NNPC Kaduna (Nigeria) petroleum refinery effluent. Ecotoxicol Environ.Safety.19: 123-134.

Osibanjo, O; Nnorom, I; Bakare, AO; Okunola, AA (2011) Environmental and public health consequences of adopting crude recovery techniques in e-waste management in developing countries: An emerging global crisis. Nova Science, Ibadan p.17.

Qing, L; Annamalai, LH; Yap, SC; Jing, T; Jeffrey, PO (2006). Persistent organic pollutants and adverse health Effects in human. J. Toxicol. Environ. Health.69: 1981 -2005.

US Environmental protection Agency. (1999). Compendium of methods for the Determination of Toxic Organic compounds in Ambient Air compendium method TO 13a, Determination of Polycychic Aromatic Hydrocarbons (PAHS) in Ambient Air using Gas chromatography/Mass spectrometing (GC/MS) Centre for Environmental research Information office of Research and Development second Edition, Cincinati, off: U.S Environmental protection Agency: p. 45258 EPA/525/R95/010b.

US -EPA/NOAA (2005) Predicting toxicity to amphipods from sediment chemistry. Washington DC: National center for Environmental Assessment. Office of research and Development. US Environmental protection Agency.

US-EPA (1998) Guidelines for ecological risk assessment. Washington DC: Us Environmental protection Agency.

Wang,Y; Zhong, G (2011) Characterization and risk assessment of PCBs in soils and vegetables near an electronic waste recycling site, South-China. Chemophere. 85(3)344-350

Wong, NH; Wong, AS (2007) Export of toxic chemicals - A review of the case of uncontrolled electronic waste recycling. Environ. Poll149: 131-140 